\title{
APLIKASI PROBIOTIK Aeromonas sobria A3-51 UNTUK REKAYASA NUTRISI DAN IMUNOMODULASI PERIFITON PAKAN ALAMI IKAN TILAPIA
}

\author{
Agus Irianto") dan Ning Iriyanti ${ }^{* *}$ \\ *) Fakultas Biologi, Universitas Jenderal Soedirman \\ Jl. Dr. Suparno No. 788, Karangwangkal, Purwokerto \\ E-mail:a_irianto2@yahoo.com \\ **) Fakultas Peternakan, Universitas Jenderal Soedirman \\ Jl. Dr. Suparno No. 788, Karangwangkal, Purwokerto
}

(Naskah diterima: 15 November 2010; Disetujui publikasi: 6 April 2011)

\begin{abstract}
ABSTRAK
Probiotik Aeromonas sobria A3-51 terbukti telah mampu menekan insiden infeksi Aeromonas hydrophila dan A. salmonicida pada berbagai jenis ikan in vitro. Aplikasi melalui pakan mengalami banyak kendala oleh sebab itu dicari metode alternatif dengan menggunakannya untuk memanipulasi komponen mikroba penyusun perifiton pakan alami ikan pada substrat bambu. Dari penelitian yang dilakukan terbukti $A$. sobria A3-51 mampu mempengaruhi karakter biofilm perifiton serta mikroba pada lingkungan perairan ketika dilakukan di kolam tanah. Faktor lingkungan cukup berpengaruh pada kualitas air seperti penetrasi sinar matahari, $\mathrm{pH}$, dan suhu. Hasil analisis proksimat menunjukkan bahwa protein perifiton cukup tinggi mencapai $22,88 \%$ $27,90 \%$ sehingga potensial digunakan sebagai bahan pakan pengganti. Adapun dari aspek imunitas, terbukti $A$. sobria A3-51 mampu menghambat pertumbuhan beragam bakteri Gram-negatif patogen ikan. Ketika dilakukan pengujian secara in vitro terhadap ikan tilapia, hasil belum menunjukkan bukti bahwa perifiton mampu meningkatkan derajat imun ikan tilapia berdasarkan gambaran darah.
\end{abstract}

KATA KUNCl: Aeromonas sobria A3-51, hematologis, nutrisi, perifiton, tilapia

ABSTRACT: Probiotic Aeromonas sobria A3-51 application to manipulate nutritional and imunomodulation values of periphyton as tilapia natural feed. By: Agus Irianto and Ning Iriyanti

Probiotic Aeromonas sobria A3-51 has been proven in suppressing A. hydrophila and $\boldsymbol{A}$. salmonicida infection in various freshwater fishes in vitro. However, there are many obstables to develope its application in feed much further. This study was an initial effort in using the probiotic to manipulate biofilm periphytone growth on bamboo substrate. The study found that A. sobria A3-51 was capable of influencing the aquatic microorganism growth both in plastic container as well as in earthen pond. The study in earthen pond was strongly affected by the quality of input water and other environmental factors such as $\mathrm{pH}$, temperature, sunlight penetration and organic matter availablity. Proximate analysis indicated that periphytone protein level induced with A3-51 was considerably high i.e. 20.41\%-21.78\% which are potential to be used as an alternative feed protein source. From immunity aspect, the study indicated that A. sobria A3-51 was capable in inhibiting the growth of various freshwater fish Gram Negative pathogens. When the periphyton was challenged as feed to tilapia in vitro, hematologic profile did not perform well. Therefore, further study on the use 
of A. sobria A3-51 in aquaculture was needed in order to manipulate the nutritional value and immunomodulatory effect of biofilm-periphyton.

\section{KEYWORDS: Aeromonas sobria A3-51, haematologic, nutrient, periphyton, tilapia}

\section{PENDAHULUAN}

Budidaya perikanan sebagian atau seluruhnya tergantung pada asupan pakan buatan (pellet). Karena populasi hewan budidaya per satuan luas tinggi, maka pencemaran dari feses atau sisa pakan terus berlangsung dan ini berakibat meningkatnya insiden wabah penyakit infeksi pada ikan. Salah satu usaha mengatasi hal tersebut adalah penggunaan pakan alami dari badan air sehingga asupan dari luar dapat diminimalkan dan tekanan pada lingkungan bisa dikurangi.

Perifiton merupakan salah satu jenis pakan ikan alami dan telah digunakan secara terbatas untuk sejumlah spesies ikan seperti tilapia (Milstein et al., 2005). Perifiton terbentuk pada substrat yang terendam dalam air. Hingga saat ini penelitian perifiton masih terbatas, umumnya berupa variasi substrat dan pemupukan (Azim et al., 2001 ab; 2005).

Pada penelitian ini usaha inovatif perbaikan kualitas perifiton dilakukan dengan cara memanipulasi mikroorganisme penyusun perifiton melalui inokulasi bakteri Aeromonas sobria A3-51 yang telah dilaporkan dapat berperan dalam meningkatkan sintasan, daya tahan terhadap penyakit infeksi dan pertumbuhan sejumlah ikan (Irianto \& Austin, 2002). Perifiton yang dihasilkan dengan manipulasi tersebut diharapkan dapat memiliki nilai keunggulan komparatif seperti kemampuan menekan mikroorganisme patogen dan merangsang pertumbuhan ikan.

Tilapia merupakan ikan air tawar yang digolongkan sebagai ikan low trophic level, bersifat herbivor dan mengkonsumsi algae, bakteri, dan detritus penyusun biofilm atau perifiton. Tilapia juga memiliki nilai komparatif untuk dikembangkan karena lebih tahan dan toleran terhadap penyakit dan kualitas air yang kurang baik (Abdel-Hakim et al., 2004).

Tujuan penelitian ini adalah untuk mengetahui penggunaan probiotik dalam memanipulasi pembentukan perifiton yang memiliki nilai komparasi lebih baik dari aspek nutrisi dan imunomodulasi bagi ikan tilapia.

\section{BAHAN DAN METODE}

\section{Bahan dan Alat}

Bahan yang digunakan meliputi kultur probiotik A. sobria A3-51, kultur patogen ikan (Aeromonas hydrophyla, Vibrio harveyii, $V$. alginolyticus, V. ordalii, V. Anguillarum, dan Yersinia ruckerii).

Bahan media pertumbuhan berupa Nutrient Agar (NA, Oxoid) Tryptone Soya Broth (TSB, Oxoid), Tryptone Soya Agar (TSA, Oxoid) dan Pseudomonas-Aeromonas Agar (Oxoid), dan rapid identification kits API 20E (Biomerieux).

Alat yang digunakan meliputi bak plastik $60 \mathrm{~cm} \times 60 \mathrm{~cm} \times 80 \mathrm{~cm}$, bambu, petridish, tabung reaksi, inkubator, otoklaf, oven, dan sebagainya.

\section{Cara Kerja}

\section{Peremajaan kultur}

Kultur koleksi mikroorganisme unggulan dari deep-freezer diremajakan dengan memasukkan pada tabung reaksi berisi media $\mathrm{TSB}$, diinkubasi pada suhu $28^{\circ} \mathrm{C}-30^{\circ} \mathrm{C}$ selama $1 \times 24$ jam. Selanjutnya, suspensi TSB digores pada media TSA dan diinkubasi $2 \times 24$ jam.

\section{Re-checking}

Setelah inkubasi 1-2×24 jam kultur yang tumbuh dari peremajaan dicek ulang karakternya untuk meyakinkan spesies yang diuji benar adanya menggunakan rapid kit API $20 \mathrm{E}$.

\section{Uji biokimiawi dan morfologi}

Uji dilakukan untuk identifikasi kultur mikroorganisme unggulan. Jika dengan API 20E positif hasilnya sama, dilakukan uji tambahan seperti uji motilitas dan beberapa uji enzimatis lainnya.

\section{Rekayasa probiotik A3-51}

Kolam tanah disiapkan dengan mencangkul atau membalik tanah, dikapur $25 \mathrm{~kg} / 100 \mathrm{~m}^{2}$ dan dipupuk dengan pupuk kandang $25 \mathrm{~kg} /$ 
$100 \mathrm{~m}^{2}$. Selanjutnya kolam dipasangi patok bambu (sekurangnya $70 \mathrm{~cm}$ terendam air) dengan bagian yang terendam harus sebanding dengan $60 \%$ luas permukaan kolam (12 batang $/ \mathrm{m}^{2}$ ). Kegiatan ini dilakukan untuk pembentukan perifiton

\section{Preparasi kultur probiotik dan perifiton}

Kultur $A$. sobria A3-51 umur 2 hari disuspensikan dalam akuades hingga konsentrasi $10^{6} \mathrm{sel} / \mathrm{mL}$, selanjutnya dituangkan dalam kolam $5 \mathrm{~L} / 100 \mathrm{~m}^{2}$, dibiarkan satu minggu. Penuangan diulang lagi dengan konsentrasi dan volume sama, dan dibiarkan hingga satu minggu kemudian, air dibiarkan tidak mengalir. Setelah dibiarkan 14 hari aliran air dibuka dengan tingkat kecepatan aliran 25\% per hari, sumber air dari saluran sekunder. Air kolam diukur $\mathrm{pH}$, suhu, kadar nitrat, kadar amonia, DO, dan $\mathrm{BOD}_{5}$. Re-inokulasi probiotik dilakukan setiap 2 minggu dengan konsentrasi dan volume sama yaitu $10^{6} \mathrm{sel} / \mathrm{mL}$ sebanyak $5 \mathrm{~L} / 100 \mathrm{~m}^{2}$.

\section{Evaluasi kestabilan perifiton dan kualitas air kolam}

Kestabilan perifiton dievaluasi dengan mengambil sampel setiap 2 minggu dari batang bambu. Begitu pula dengan kualitas air $(\mathrm{pH}$, suhu, DO, kadar nitrat, amonia, dan $\mathrm{BOD}_{5}$ ) dan total mikroba pada air.

\section{Pengukuran pertumbuhan bakteri probiotik A. sobria A3-51}

Masing-masing sampel air diproses dengan satu seri pengenceran sebelum ditabur secara spread plating ke dalam petridish berisi Pseudomonas-Aeromonas Agar (Oxoid) dan diinkubasi $30-32^{\circ} \mathrm{C}$ selama $2 \times 24$ jam dan untuk kaji silang dilakukan pula penaburan pada nutrient agar (Oxoid) secara duplo.

\section{Pengukuran nilai nutrisi perifiton}

Setelah pemeliharaan 4 minggu maka perifiton yang tumbuh pada batang bambu dikerok dengan scalpel secukupnya dan dikeringkan dalam oven hingga berat stabil. Selanjutnya dianalisis nilai proksimatnya (kadar lemak, karbohidrat, protein).

\section{Pengukuran senyawa antimikroba dari bakteri probiotik A3-51}

Bakteri probiotik A. sobria A3-51 dianalisis aktivitas senyawa antimikrobanya melalui uji gores terhadap Aeromonas hydrophila dan patogen ikan.

\section{Pemberian perifiton untuk ikan tilapia}

Siapkan bak plastik ukuran $60 \mathrm{~cm} \times 30 \mathrm{~cm}$ $x 30 \mathrm{~cm}$ sebanyak 2 untuk kontrol dan 2 untuk perlakuan, diisi dengan ikan tilapia masingmasing sebanyak 10 ekor ukuran $\sim 25 \mathrm{~g}$. Setiap hari untuk kontrol diberi pakan sebanyak $3 \%$ pakan pelet komersial/bobot badan ikan, sedangkan pada ikan perlakuan diberi pakan sebanyak $1,2 \%$ pakan komersial dan disuplai bambu yang ditumbuhi perifiton dari kolam tanah yang sebanding dengan 3 batang bambu ukuran $50 \mathrm{~cm}$.

\section{Variabel yang diamati}

Variabel yang diamati meliputi: pertumbuhan perifiton dan komposisi mikroorganisme penyusunnya, nilai nutrisi pakan (nilai proksimat), kualitas air (pH, DO, kadar nitrat, amonia), dan pengukuran luasan zona penghambatan A. hydrophila, gambaran darah ikan tilapia.

\section{HASIL DAN BAHASAN}

Hasil pengujian kultur beku A. sobria A351 dengan rapid test kit API 20E Biomerieux, menunjukkan bahwa kultur masih murni dengan karakter seperti awal mulanya yaitu identik dengan $A$. sobria A3-51. Pengujian terhadap kultur $A$. sobria A3-51 dilanjutkan dengan melakukan uji antibiosis terhadap sejumlah bakteri patogen ikan, adapun hasilnya ditunjukkan pada Tabel 1 .

Tabel 1 menunjukkan bahwa $A$. sobria A3-51 menghambat pertumbuhan bakteri patogen yang diujikan kecuali $Y$. ruckerii, adapun derajat penghambatannya bervariasi. A. hydrophila merupakan patogen yang paling sensitif terhadap $A$. sobria A3-51. Pada penelitian terdahulu, $A$. sobria menunjukkan kemampuan kuat dalam menghambat bakteri patogen berupa Aeromonas salmonicida dan A. salmonicida achromogenes (Irianto \& Austin, 2002). A. salmonicida merupakan patogen ikan tawar perairan beriklim sedang, adapun $A$. salmonicida achromogenes dijumpai pula pada lingkungan tropik.

Pada Tabel 2 tampak bahwa di kolom air penghitungan bakteri total pada kontrol cenderung lebih tinggi, sebagian populasi bakteri pada kolam dengan substrat perifiton cenderung mencari pelekatan atau tempat 
Tabel 1. Pengujian daya hambat kultur A3-51 terhadap patogen ikan secara goresan Table 1. Inhibition test of A3-51 culture on fish pathogen by cross-streak method

\begin{tabular}{lclc}
\hline $\begin{array}{c}\text { Patogen ikan } \\
\text { Fish pathogens }\end{array}$ & $\begin{array}{c}\text { Jarak hambatan } \\
\text { Inhibition } \\
\text { diameter }(\mathbf{c m})\end{array}$ & $\begin{array}{c}\text { Patogen ikan pathogens } \\
\text { Fish }\end{array}$ & $\begin{array}{c}\text { Jarak hambatan } \\
\text { Inhibition } \\
\text { diameter }(\mathbf{c m})\end{array}$ \\
\hline Aeromonas hydrophyla & 3.2 & V. alginolyticus & 1.2 \\
Vibrio harveyii & 1.25 & V. ordalii & 1.0 \\
Yersinia ruckerii & 0 & V. anguillarum & 2.5 \\
\hline
\end{tabular}

Tabel 2. Penghitungan total mikroba pada kolom air dan permukaan substrat bambu Table 2. Total microbial count in water column and substrate surface of bamboo

\begin{tabular}{lccc}
\hline \multirow{2}{*}{$\begin{array}{c}\text { Penghit ungan mikroba } \\
\text { Microbial count (CFU/mL) }\end{array}$} & \multicolumn{3}{c}{ Minggu ke (Week to) } \\
\cline { 2 - 4 } & $\mathrm{I}$ & $\mathrm{III}$ & $\mathrm{V}$ \\
\hline TPC Periphyton (treatment with A3-51) & $2.2 \times 10^{6}$ & $4.4 \times 10^{9}$ & $6.3 \times 10^{9}$ \\
Total bacteria of A. sobria A3-51 & $5.0 \times 10^{5}$ & $3.3 \times 10^{5}$ & $1.8 \times 10^{5}$ \\
(media Pseudomonas-Aeromonas Agar) & & & \\
TPC Control (water column) & $8.35 \times 10^{5}$ & $2.04 \times 10^{10}$ & $1.09 \times 10^{10}$ \\
TPC Treatment of A3-51 (water column) & $7.98 \times 10^{5}$ & $9.94 \times 10^{9}$ & $3.66 \times 10^{9}$ \\
\hline
\end{tabular}

tumbuh pada bambu dengan jumlah total bakteri yang tinggi. Hal ini membuktikan bahwa bakteri perairan cenderung mencari tempat pelekatan sebagaimana disampaikan oleh Stevenson (1977).

Selama penelitian nilai $\mathrm{pH}$ dan suhu relatif sama. Nilai pH cenderung netral (pH 6-7). Adapun dalam hal suhu air, selama penelitian suhu air ada pada kisaran $26^{\circ} \mathrm{C}-27^{\circ} \mathrm{C}$.

Pengamatan terhadap nilai $\mathrm{BOD}_{5}$ kontrol dan perlakuan menunjukkan nilainya terus menurun. Penurunan tersebut berasal dari sumber air dan aktivitas mikroorganisme dalam lingkungan kolam. Pada kolam dengan perifiton yang dimanipulasi menggunakan probiotik A351 penurunan $\mathrm{BOD}_{5}$ lebih besar (Gambar 1 ).

Dalam penelitian ini kolam tidak ditaburi ikan sehingga bahan organik di dalamnya berasal sepenuhnya dari sumber air. Introduksi kultur A. sobria A3-51 terbukti berperan dalam mendekomposisi bahan organik lebih baik ditunjukkan oleh nilai $\mathrm{BOD}_{5}$ yang lebih rendah hal ini sejalan dengan pernyataan Verschuere et al. (2000) bahwa probiotik dalam akuakultur juga berperan dalam dekomposisi materi organik.
Mikroorganisme heterotrofik sebagaimana A. sobria A3-51, akan mendekomposisi materi organik. Dekomposisi protein pada akhirnya akan menghasilkan amoniak yang merupakan salah satu senyawa $\mathrm{N}$ yang dapat digunakan oleh jasad ototrof seperti algae. Pada Gambar 2 terlihat bahwa penurunan kadar amoniak pada perlakuan perifiton yang diinduksi oleh A3-51 lebih rendah menunjukkan bahwa kemungkinan amoniak digunakan oleh alga yang lebih melimpah pada perlakuan tersebut dan atau transformasi menjadi nitrit dan selanjutnya menjadi nitrat berlangsung dengan lebih cepat. Hal ini seperti pada Gambar 2 yang memperlihatkan kandungan nitrat yang tinggi pada perlakuan dengan $A$. sobria A3-51.

Kadar amoniak dan kadar nitrat yang ditunjukkan pada Gambar 2 masih pada kisaran normal bagi kehidupan ikan dan organisme periaran pada umumnya. Ikan seperti tilapia, pada kandungan oksigen terlarut normal akan menyebabkan kematian pada konsentrasi 1 $\mathrm{mg} / \mathrm{L}$ atau lebih (Boyd, 1991).

Pengamatan terhadap alga menunjukkan bahwa pada perlakuan dalam mikrokosmos bak 


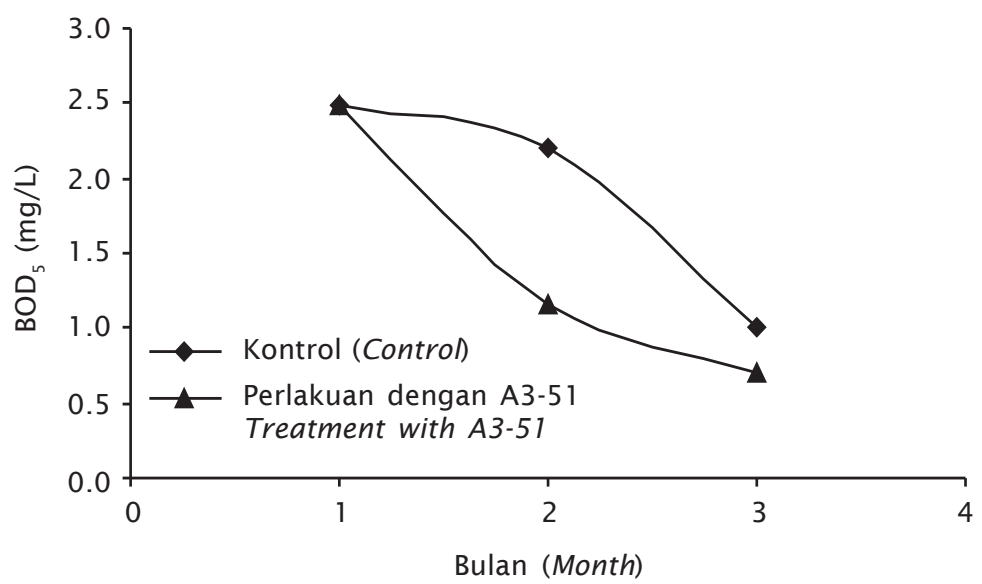

Gambar 1. Nilai $\mathrm{BOD}_{5}$ perairan kolam antara kontrol dan perlakuan

Figure 1. $\mathrm{BOD}_{5}$ value of pond water between control and treatments

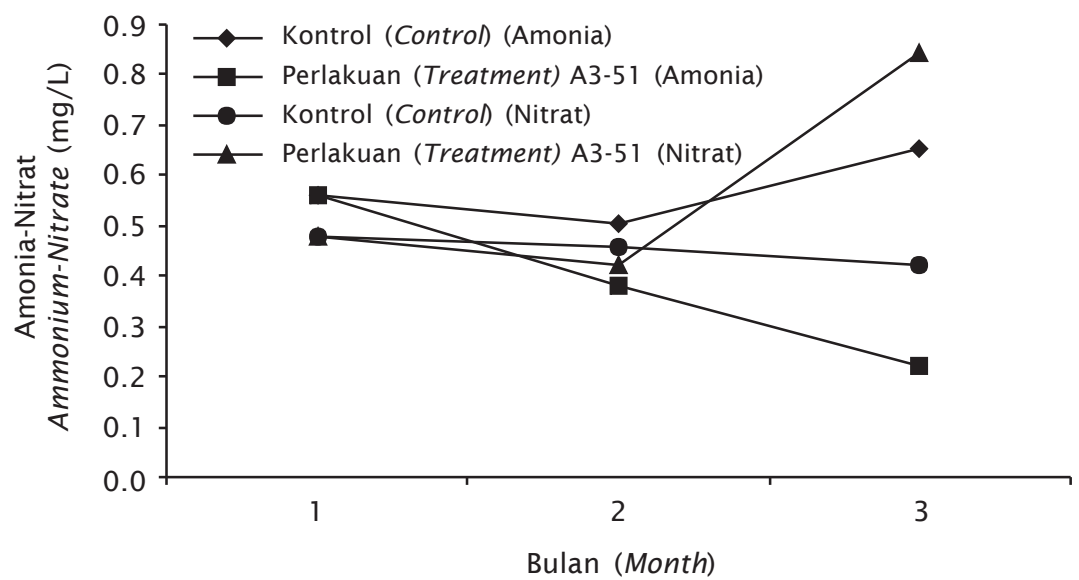

Gambar 2. Dinamika kadar amoniak dan nitrat selama penelitian

Figure 2. Ammonia and nitrate concentrations dynamic during the study

plastik, total populasi alga pada kolom air pada perlakuan dengan inokulasi A3-51 relatif lebih tinggi dibanding kontrol. Hal yang sama juga terlihat pada penelitian kolam tanah. Dibandingkan keadaan awal ketika air mulai diisikan ke kolam dengan keadaan pada minggu ke-3 setelah penelitian berlangsung, jenis alga dan kelimpahan individu per liter menurun, tetapi pada kolam berisi tonggak bambu substrat perifiton dan inokulasi $A$. sobria A3-51, jenis alga lebih rendah tetapi kelimpahannya lebih tinggi dari kolam kontrol (Tabel 3).

Analisis kandungan klorofil menunjukkan bahwa pada kolam berisi tonggak bambu substrat perifiton dan inokulasi $A$. sobria A351 , kadar klorofilnya sedikit lebih tinggi dari kontrol (Gambar 3), tetapi tingkat produktivitas primer kolom air pada kolam perlakuan cenderung lebih rendah (Tabel 4).

Dengan adanya substrat maka biofilm terbentuk oleh inisiasi sel-sel bakteria, substansi eksopolisakarida (glikokaliks) yang digunakan untuk melekat akan menjadi pelekat dan atraktan bagi mikroorganisme lain termasuk alga (Lawrence et al., 2008). Bakteri, alga dan protozoa dan sebagainya selanjutnya akan membentuk biomassa perifiton, dengan demikian produktivitas primer kolom air yang sedikit rendah disebabkan sebagian 
Tabel 3. Jenis alga dan kelimpahan alga

Table 3. Types of algae and their abundance

\begin{tabular}{|c|c|c|c|c|c|c|c|c|}
\hline \multirow{2}{*}{$\begin{array}{c}\text { Jenis } \\
\text { Pengamat an } \\
\text { Observation }\end{array}$} & \multicolumn{4}{|c|}{$\begin{array}{l}\text { Kont rol, bulan ke } \\
\text { Control, month of }\end{array}$} & \multicolumn{4}{|c|}{$\begin{array}{l}\text { Perlakuan A3-51, bulan ke } \\
\text { Treatment with A3-51, month of }\end{array}$} \\
\hline & I & II & III & IV & I & II & III & IV \\
\hline $\begin{array}{l}\text { Jenis alga } \\
\text { Types of algae }\end{array}$ & 22 & 12 & 12 & 16 & 19 & 11 & 14 & 13 \\
\hline \multicolumn{9}{|l|}{ Kelimpahan } \\
\hline $\begin{array}{l}\text { Abundance } \\
\text { (individu/L) }\end{array}$ & 15.69 & 10.03 & 7.70 & 11.99 & 85.10 & 7.23 & 18.08 & 20.28 \\
\hline
\end{tabular}

Tabel 4. Produktivitas primer kolam tanah (minggu ke-2)

Table 4. Primary productivity of the earthen ponds (week 2)

\begin{tabular}{|c|c|c|c|c|c|c|}
\hline \multirow{3}{*}{$\begin{array}{l}\text { Pengamatan } \\
\text { Subject }\end{array}$} & \multicolumn{2}{|c|}{$\begin{array}{l}\text { Bulan } \\
(\text { Month }) \text { I }\end{array}$} & \multicolumn{2}{|c|}{$\begin{array}{c}\text { Bulan } \\
(\text { Month) II }\end{array}$} & \multicolumn{2}{|c|}{$\begin{array}{c}\text { Bulan } \\
(\text { Month) III }\end{array}$} \\
\hline & $\mathrm{K}$ & $\mathbf{P}$ & $\mathrm{K}$ & $\mathbf{P}$ & $\mathrm{K}$ & $\mathbf{P}$ \\
\hline & C & $\mathbf{T}$ & C & $\mathbf{T}$ & C & $\mathbf{T}$ \\
\hline $\begin{array}{l}\text { Produktivitas primer }\left(\mathrm{mg} \mathrm{C} / \mathrm{m}^{3} / 6 \mathrm{jam}\right) \\
\text { Primary productivity }\left(\mathrm{mg} \mathrm{C} / \mathrm{m}^{3} / 6 \mathrm{hrs}\right)\end{array}$ & 145.8 & 192.7 & 62.5 & 31.3 & 171.9 & 72.9 \\
\hline
\end{tabular}

Keterangan (Note) :

$\mathrm{K}=$ Kontrol; $\mathrm{P}=$ Perlakuan dengan $A$. sobria A3-51 dan substrat perifiton

$C=$ Control; $T=$ Treatment with A. sobria A3-51 and periphyton substrate

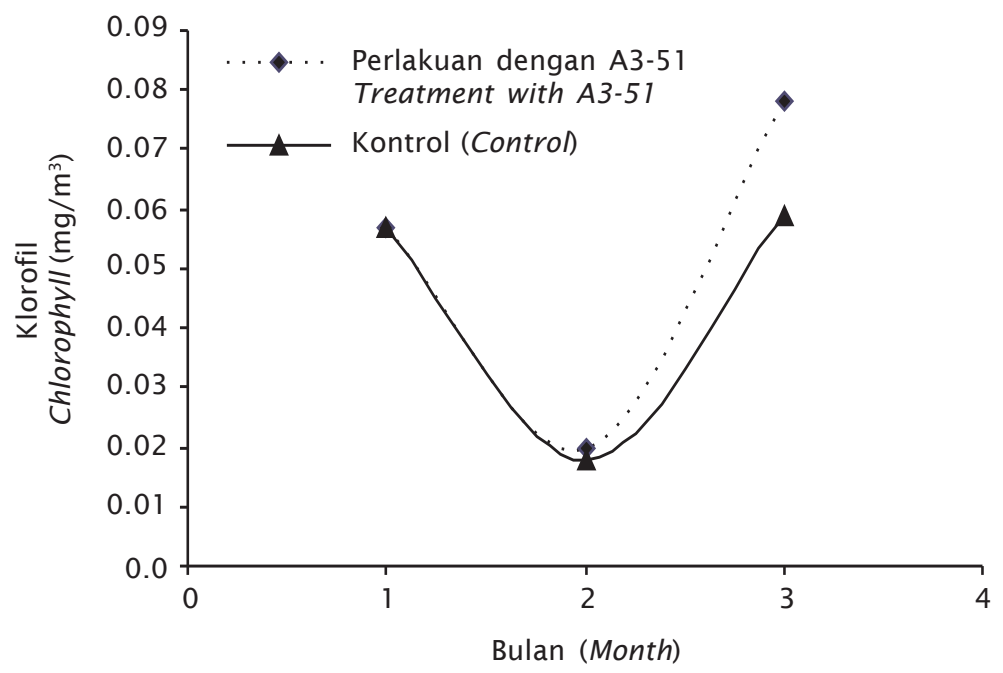

Gambar 3. Kadar klorofil pada kolom air kolam

Figure 3. Chlorophyll level in the ponds water column 
penyusunnya menjadi komponen penyusun perifiton.

Pengukuran kualitas perifiton didasarkan pada komponen-komponennya menunjukkan bahwa kandungannya seperti pada Tabel 5 .

Tabel 5 menunjukkan bahwa nilai protein perifiton relatif tinggi. Pemeliharaan selama sekitar empat bulan menunjukkan bahwa nilai protein sedikit menurun tetapi serat dan lemak meningkat. Melihat kandungan protein yang lebih dari 20\% memungkinkan menjadi alternatif sumber pakan murah berkualitas untuk ikan budidaya.

Adapun darah ikan tilapia setelah perlakuan ditunjukkan pada Tabel 6 .

Penelitian yang dilakukan oleh Mlay et al. (2007) menunjukkan bahwa pada keadaan normal, ikan Oreochromis niloticus memiliki kandungan protein darah 1,9-7,0 g/dL atau rata-rata 3,8 g/dL. Tabel 6 menunjukkan bahwa protein darah ikan tilapia pada semua perlakuan masih dalam kisaran tersebut. Selain itu, kandungan imunoglonulin relatif tinggi (> $1 \mathrm{~g} / \mathrm{dL}$ ) yang menunjukkan bahwa pada semua perlakuan, ikan pada kondisi keseimbangan fisiologis. Namun demikian, Tabel 6 juga menunjukkan bahwa perlakuan (P) relatif lebih tinggi dibandingkan dengan perlakuan lainnya, mengindikasikan bahwa pemberian probiotik $(\mathrm{P})$ memperbaiki kualitas imunoglobulin. Gambaran polymorphonuclear leukocytes (PMN) darah seperti netrofil, limfosit, dan monosit meningkat bagus apabila dibandingkan dengan kontrol, ini artinya kekebalan ikan terutama kekebalan selulernya lebih bagus. Hal ini merupakan nilai tambah dari penelitian ini.

PCV (Pack Cell Volume) atau VPRC (the Volume of Packed Red Cell), disebut pula sebagai hematokrit menunjukkan nilai volume semua eritrosit dalam $100 \mathrm{~mL}$ darah, disebut dengan persen dari volume darah dan biasanya nilai tersebut ditentukan dengan darah vena atau darah kapiler. PCV ikan percobaan menunjukkan kondisi normal. Menurut Clark et al. (1976) dalam Kori-siakpere et al. (2005), nilai hematokrit ikan 20\%-35\%, jarang yang lebih dari 50\%.

Jumlah eritrosit semua perlakuan menunjukkan ada pada kisaran normal, sebagaimana disampaikan oleh Badawi \& Said (1971) jumlah eritrosit berkisar 0,89-1,54 juta sel/dL. Adapun Lagler et al. (1977) menyatakan bahwa kadar sel darah ikan berkisar 0,02-3 juta sel/dL.

Hemoglobin atau $\mathrm{Hb}$ merupakan metaloprotein pembawa oksigen atau pigmen respirasi (Moyes \& Schulte, 2008). Nilai $\mathrm{Hb}$ darah ikan tilapia menunjukkan sedikit lebih rendah dari kadar normal, Badawi \& Said (1971) menyatakan bahwa kadar $\mathrm{Hb}$ pada beragam spesies tilapia berkisar 6,\%3-8,7\%.

Leukosit merupakan komponen darah seluler yang berperan penting dalam pertahanan tubuh terhadap serangan penyakit. Tabel 2 menunjukkan bahwa ikan pada semua perlakuan memiliki kandungan leukosit pada kisaran normal sebagaimana disampaikan Lagler et al. (1977) bahwa jumlah leukosit ikan berkisar 20.000-150.000 sel/ $\mu \mathrm{L}$. Akan tetapi jika merujuk pada Salasia et al.

Tabel 5. Analisis proksimat perifiton

Table 5. Proximate analysis of periphyton

\begin{tabular}{|c|c|c|c|c|c|c|}
\hline \multirow{2}{*}{$\begin{array}{l}\text { Sampel } \\
\text { Sample }\end{array}$} & \multirow{2}{*}{$\begin{array}{l}\text { Air } \\
\text { Water } \\
(\%)\end{array}$} & \multirow{2}{*}{$\begin{array}{l}\text { Bobot kering } \\
\text { Dry weight } \\
\text { (\%) }\end{array}$} & \multicolumn{4}{|c|}{ \% Bobot kering (Dry weight) } \\
\hline & & & $\begin{array}{l}\text { Protein } \\
\text { Protein }\end{array}$ & $\begin{array}{l}\text { Lemak } \\
\text { Lipid }\end{array}$ & $\begin{array}{l}\text { Serat } \\
\text { Fiber }\end{array}$ & $\begin{array}{l}\text { Abu } \\
\text { Ash }\end{array}$ \\
\hline $\begin{array}{l}\text { Kontrol bulan II } \\
\text { Control, month II }\end{array}$ & 93.68 & 6.30 & 24.60 & 9.82 & 14.08 & 40.30 \\
\hline $\begin{array}{l}\text { Bulan IV } \\
\text { Month of IV }\end{array}$ & 98.24 & 1.75 & 19.30 & 11.09 & 32.88 & 26.48 \\
\hline $\begin{array}{l}\text { Perlakuan bulan II } \\
\text { Treatment, month II }\end{array}$ & 92.49 & 7.50 & 27.90 & 12.16 & 11.95 & 38.44 \\
\hline $\begin{array}{l}\text { Bulan IV } \\
\text { Month of IV }\end{array}$ & 93.75 & 6.25 & 22.88 & 15.23 & 34.68 & 17.64 \\
\hline
\end{tabular}


Tabel 6. Gambaran darah ikan tilapia pada akhir pemeliharaan Table 6. Blood profile of tilapia at the end of rearing period

\begin{tabular}{|c|c|c|}
\hline \multirow{3}{*}{ Parameter } & \multicolumn{2}{|c|}{$\begin{array}{l}\text { Akhir pemeliharaan } \\
\text { At the end of rearing }\end{array}$} \\
\hline & K & $\mathbf{P}$ \\
\hline & C & $\mathbf{T}$ \\
\hline Total protein $(\mathrm{g} / \mathrm{dL})$ & 5.9 & 3.2 \\
\hline Albumin $(\mathrm{g} / \mathrm{dL})$ & 4.1 & 2.4 \\
\hline Globulin (g/dL) & 2.3 & 1.2 \\
\hline Immunoglobulin (g/dL) & 1.78 & 2 \\
\hline Ery throcy te (million/ $\mu \mathrm{L}$ ) & 2.18 & 2.11 \\
\hline Leucocyte (thousand/ $\mu \mathrm{L}$ ) & 41.0 & 28.5 \\
\hline Neutrophil (\%) & 49.5 & 55 \\
\hline Limphocyte (\%) & 28 & 40 \\
\hline Monocyte (\%) & 9 & 13.5 \\
\hline Value of PCV (\%) & 29.5 & 27.5 \\
\hline Concentration of $\mathrm{Hb}(\mathrm{g} / \mathrm{dL})$ & 6.0 & 5.5 \\
\hline $\operatorname{TPP}(\mathrm{g} / \mathrm{dL})$ & 5.2 & 4.7 \\
\hline
\end{tabular}

Keterangan (Note) :

$\mathrm{K}=$ Kontrol; $\mathrm{P}=$ Perlakuan dengan $\mathrm{A}$. sobria $\mathrm{A} 3-51$ dan substrat perifiton

$C=$ Control; $T=$ Treatment with $A$. sobria A3-51 and periphyton substrate

(2001) dan Martins et al. (2008), jumlah leukosit di atas jumlah tersebut menjadi indikator adanya leukositosis sebagai akibat terjadinya infeksi.

Dari hasil yang diperoleh pada penelitian ini menunjukkan bahwa komponen-komponen darah putih berupa neutrofil di atas kadar normal, sedangkan limfosit di bawah kadar normal. Adapun monosit masih pada kisaran normal. Menurut Salasia et al. (2001), konsentrasi neutrofil pada ikan tilapia jantan berkisar 5,0 $\pm 2,83 \%$, eosinofil 5,75 $\pm 4,86 \%$, limfosit 78,83 $\pm 14,32 \%$ dan monosit 12,50 \pm $8,24 \%$. Rendahnya kadar monosit (terutama pada K), tingginya kadar neutrofil dan leukosit secara keseluruhan semakin memperkuat indikasi bahwa diduga ikan kontrol sedang mengalami infeksi.

Hasil pengamatan terhadap TPP (Total Protein Plasma) menunjukkan bahwa semua perlakuan sedikit lebih tinggi. Menurut Salasia et al. (2001), nilai TPP ikan tilapia sebesar 3,90 $\pm 0,25 \mathrm{~g} / \mathrm{dL}$.

\section{KESIMPULAN}

Penggunaan kultur probiotik A3-51 untuk memanipulasi mikroba penyusun perifiton terbukti dapat memperbaiki kualitas lingkungan budidaya serta menghasilkan perifiton yang potensial untuk pakan ikan pengganti pakan komersial. Akan tetapi pengamatan percobaan in vitro belum menunjukkan bukti yang cukup bahwa perifiton yang diinduksi probiotik A. sobria A3-51 meningkatkan derajat imun ikan tilapia berdasarkan gambaran hematologisnya.

\section{UCAPAN TERIMA KASIH}

Terima kasih kepada DP2M Ditjen Dikti Kementrian Pendidikan Nasional yang telah mendanai penelitian ini melalui hibah kompetensi untuk tahun 2009 dan 2010.

\section{DAFTAR ACUAN}

Abdel-Hakim, N.F.; Amar, A.A., \& Bakeer, M.N. 2004. Effect of stocking density and feeding systems on growth performances of nile tilapia (Oreochromis niloticus) reared in concrete tanks. J. Egut. Acad. Soc. Environ. Develop. B. Aquaculture. 5(2): 871005.

Azim, M.E., Wahab, M.A., van Dam, A.A., Beveridge, M.C.M., \& Verdegem, M.C.J. 2001 a. The potential of periphyton-based 
culture of two Indian Major carps, rohu (Lobeo rohita) (Hamilton) and gonia (Lobeo gonius Linnaeus). Aquaculture Research, 32: 209-216.

Azim, M.E., Verdegem, M.J.C., Wahab, M.A., van Dam, A.A., \& Beveridge, M.C.M. 2001b. Periphyton boosts production system in pond aquaculture systems. World Aquaculture, p. 51-67.

Azim, M.E.; Wahab, M.A., Verdegem, M.C.J., van Dam, A.A., Beveridge, M.C.M., Little, D.C., \& Komatsu, T. 2005. Periphyton-based aquaculture production: an ecological approach. World Aquaculture Symposium May 9-13, 2005. Nusadua, Bali.

Badawi, H.K. \& Said, V.L.M. 1971. A comparative study of the blood of four Tilapia species (Pisces). Marine Biology, 8: 202-204.

Boyd, C.E. 1991. Water quality management and aeration in shrimp farming. Proyek Penelitian dan Pengembangan Perikanan, Pusat Penelitian dan Pengembangan Perikanan. Jakarta.

Gomez-Gil, B., Herrera-Vega, M.A., AbreuGrobois, F.A., \& Roque, A. 2002. Bioencapsulation of Two Different Vibrio Species in Nauplii of the Brine Shrimp (Artemia franciscana). Applied and Environmental Microbiology, 64(6): 2318-2322.

Irianto, A. \& Austin, B. 2002. Use of probiotic to control furunculosis in rainbow trout (Oncorhynchus mykiss Walbaum). Journal of Fish Diseases, 25: 333-342.

Irianto, A. \& Austin, B. 2003. Use of formalininactivated cells of Aeromonas hydrophila A3-51 to control infection by atypical Aeromonas salmonicida in goldfish, Carassius auratus L. Journal of Fish Diseases, 27: 40-43.

Kori-Siakpere, O., Ake, J.E.G, \& Idoge, E. 2005. Haematological characteristics of the African snakehead, Parachanna obscura. African Journal of Biotechnology, 4(6): 527-530.

Lagler, K.F., Bardach, J.E., Miller, R.R., \& Passino, R.R.M. 1977. Ichthyology. $2^{\text {nd }}$ Ed. John Wiley \& Sons, Toronto.
Lawrence, J.R., Zhu, B., Swerhone, G.D.W., Topp, E., Roy, J., Wassenaar, L.I., T. Rema, 3 \& D.R. Korber3. 2008. Community-Level Assessment of the Effects of the BroadSpectrum Antimicrobial Chlorhexidine on the Outcome of River Microbial Biofilm Development. Applied and Environmental Microbiology, 74(11): 3541-3550.

Martins, M.L., Mouriño, J.L.P., Amaral, G.V. G.V., Vieira, F.N., Dotta, G., Jatobá, A.M.B., Pedrotti, F.S., Jerônimo, G.T., Buglione-Neto, C.C., \& Pereira-Jr, G. 2008. Haematological changes in Nile tilapia experimentally infected with Enterococcus sp. Braz. J. Biol. vol.68 no.3. http://www.scielo.br/ s c i e I o.ph p ? p id = S 1519 $69842008000300025 \&$ script $=$ sci_arttext. Diakses tanggal 27 Nopember 2009.

Milstein, A., Joseph, D., Peretz, Y., \& Harpaz, S. 2005. Evaluation of organic tilapia culture in periphyton-based ponds. The Israeli Journal of Aquaculture, Bamidgeh,. 57(3): 143155.

Mlay, P.S., Seth, M., Balthazary, S.T., Chibunda, R.T., Phiri, E.C.J.H., \& Balemba, O.B. 2007. Total plasma proteins and hemoglobin levels as affected by worm burden in freshwaterfish in Morogoro, Tanzania. Livestock Research for Rural Development 19 (2). http://www.Irrd.org//rrd19/2/ mlay19019.htm. diakses 27 Nopember 2009.

Moyes, C. \& Schulte, P. 2008. Principles of Animal Physiology. $2^{\text {nd }}$ Edition. Pearson Benjamin Cummings. San Fransisco.

Salasia, S.I.O, Sulanjari, D., \& Rahmawati, A. 2001. Studi hematologi ikan air tawar. Biologi, 2(12): 710-723.

Stevenson, L.H. 1977. A case for bacterial dormancy in aquatic systems Microbial. Ecology, 4(2): 127-133.

Verschuere, L., Rombaut, G., Sorgeloos, P., \& Verstraete, W. 2000. Probiotic bacteria as biological control agents in aquaculture. Microbiology and Molecular Biology Reviews, 64: 655-671. 